\title{
Editorial: Phenomenological Research is Existential
}

Tone Saevi, Editor, VID Specialized University, Norway

Email:tone.saevi@vid.no

Phenomenology explores phenomena, that in one way or another, are present to humans as and in lived experiences. A lived experience is the sensed contact with what is outside oneself; although what is outside oneself, $a$ s and in experience, is always subjectively lived by the person experiencing the moment. As human beings we cannot not relate to what is outside us in an inside way. That is, as subjects, we, in some way or another, sense or become aware cognitively or non-cognitively of the other, the thing, the situation, or the event. Existence is a human condition even more basic than plurality (Arendt 1958), although the two happen simultaneously to the human being. Said more directly, as human beings we exist among others, things, situations, events, nature, culture - we are immersed in them - therefore, we cannot experience outside of existence.

This means that phenomenology has an interest in questions related to how human beings exist, or in everyday terms, how we experience phenomena in life, and how we try to realize these experiences in actions and words. We exist in life, and we encounter the world which surrounds us in infinite ways. The fact is that phenomenology, like all other methodological and substantial research approaches, is bound to explore aspects of existence in its endeavor to understand the world, whether the world is a concrete phenomenon, or represents an orientation to theoretical perspectives, concepts, regularities or patterns. To Merleau-Ponty (1945) the various research methods relate to a question of primary or secondary approaches. All approaches relate to existence as the very condition for research whether the existential is visible and palpable or not, if it is explicit or implicit.

Existence understood as life, and the way we live our lives, has been a human science issue long before Husserl, and with Heidegger, human existence - as Dasein or Being - was perhaps at the fulcrum of his lifework. Derrida (in Caputo, 1997) gives credit to Heidegger as the philosophical pioneer of deconstruction (with his term Ab-bauen). Existential phenomenology is a profound deconstructive work. "Doing phenomenology" as van Manen (2014) reiterates, is the methodological effort to work toward the core of a phenomenon, which as such always de-constructive-ly relates to and originates from existence.

Phenomenology \& Practice $(P \& P)$ portrays a double existential practice; first, by the mere act of publishing phenomenological articles, and second through the act of publication, the editors and authors open the world to exploration based on a myriad of existential practices. Phenomenologists borrow from qualitative research, the empirical interests in peoples' experiences of things in life, and let descriptions of a phenomenon create the heart of the phenomenological investigation. However, unlike qualitative researchers, the phenomenologist orients to the experience and to aspects of a phenomenon, instead of orienting to the person or the expression behind the experience. Rather than social realistic descriptions of an individual or a group's experiences, or developing patterns, theories, or 
generalizations, a phenomenologist is looking for the invariable qualities of a unique phenomenon.

\section{Talking Truth}

Building a boat, playing a pipe-organ, saying goodbye to your child the first school day, driving an old car, and asking questions to students, are phenomena under exploration in this current $P \& P$ issue. These phenomena of everyday experiences, may very well be the experience of some of our readers who are professionals, parents, or teachers. For others, these are human experiences that are potentially possible, and thus, existential in that they are human experiences in words and acts. Lived experience belongs to our existence as human beings, and cannot be distinguished from or removed from the lives we live. A lived experience is "taken out of the continuity of life and at the same time related to the whole of one's life" (Gadamer, 1985, p. 62). The phenomenologically meaningful lived example is distinguished from the rest of life's web by being told, written, honed and increasingly made sense of. And at the same time, the lived example - like saying goodbye the first school day, or playing a pipe organ - inserts itself in life and adds sense to the self and to the life of the person (Henriksson \& Saevi, 2010, p. 47). Phenomenology does not claim privileged access to truth or accurate measurable knowledge, nor do we ask as phenomenologists, whether what we unveil is a definite truth. Gadamer (1985), by reference to Vico, the Italian 18th century philosopher, points to the old truth of common sense, and the classic human ideal of wisdom as a mode of knowledge: "“Talking well" (eu legein) has always two meanings; it is not merely a rhetorical ideal. It also means saying the right thing, i.e. the truth, and is not just the art of speaking or saying whatsoever well" (p. 19). The possibility of meaning is somehow always inscribed in the transcendence of the lived experience. In fact, Heidegger (1962) asserts, "Higher than actuality, stands possibility" (p. 63), and in one form or another, this principle is true for phenomenology.

Thus, turning to the lived experience is to listen to the speaking of the things of the world; the wood of the boatbuilder, the work of the organ player in making music, the response of the mother or father to the child on the first day of school, the driver of the wellknown old car, and the teacher questioning young students. In order to investigate the possibilities of these phenomena, experience is evoked and illuminated but never pinned down in a closed system of concepts.

\section{A Breath of Meaning Rather than Provable Knowledge}

The paradox is that phenomenology strives to see the world as it is immediately experienced, although the world can only be grasped retrospectively by reflecting on the already past experience. Paradoxically then, the awareness of the lived experience is to try to grasp an experience which is unaware of itself. This unawareness Dilthey (1971) calls "a breath of meaning," an instantaneous, yet elusive sense of a deeper understanding that somehow seems to escape cognition. In a fundamental sense, lived experience always already assumes a certain shape or meaning for us, which constantly covers the ground of our being our existence and existential experience, and prompts us to believe that we already understand the experience. In Kirk and Raven's (1957) words, phenomenology thinks the experience twice in order to recollect fundamental meaning that may have been forgotten in the rush of things: 
[Phenomenology] is the systematic search for the integral meaning of experience; it is "bethinking", not as a mere bringing to consciousness, but as a careful, englobing recollection of a fundamental meaning implicit to experience, though forgotten in the rush of things; and it is "of "truth", not as a sum of correct assertions, but as the "intelligibility" [...] by which all things are steered through all things. (p. 204, as cited in Burch (1989), p. 11)

Human science phenomena are like Marcel (1951) would have said it, not problems in need of solutions but are in a certain sense mysteries in need of evocative and thoughtful comprehension. This does not mean that a phenomenon is mysterious in the meaning less realistic or less substantive. Rather, "the human phenomenon in investigation needs to be reachieved contact with, so that we, in a certain way, may recapture its primordial reality" (Saevi, 2005, p. 84).

Wittgenstein (1982-1992) speaks of the astonishment that sometimes strikes us when we recognize that everything exists. The thatness of the things of the world, makes us wonder and surprises us with its pure existence. Wittgenstein calls this response to the world, as well as our relationality to all that surrounds us, a «feeling that we are dependent on an alien will. In a certain sense, dependent and that on which we depend, we can call God» (Wittgenstein, 1982-1992, p. 32). Wood (2002) goes further, and sees the astonishment that anything exists as not just any experience. It is rather one of the fundamental existential experiences. One might see this existential astonishment and wonder of the thatness of the world, as gratefulness to God or to faith or destiny, in that there is always a wondering gratefulness to something that is outside the human being. As Wood (2002) says, "The world of the grateful man lights up in ways that the ungrateful man's does not" (p. 24). The point to this response is the willingness to stay with the experience that is not of our making or doing, but given to us in life and existence.

\section{Seeing the World}

I finally understood that it is not sufficient phenomenologically to address a phenomenon, but the phenomenon as well should address me. The well-known British author C.S. Lewis leads his readers into many worlds, times, spaces and levels of experience. His fictional movements beyond our shared real world into fantastic imagined worlds, might have opened an insight to him of how we actually see what we see. He writes:

The whole point of seeing through something is to see something through it. It is good that the window should be transparent, because the street or garden beyond is opaque. How if you saw through the garden too? It is no use trying "to see through" first principles. If you see through everything, then everything is transparent. But a wholly transparent world is an invisible world. To see through all things is the same as not to see. (Lewis, 1986, p. 48)

Phenomenology is very much a realistic project. It is an exploration into our lives and lifeworlds - the puzzling, the complex, and sometimes the unintelligible world we live in and the experiences we live through. The phenomenon is not a theoretical concept but an existing thing, a substance, an existential that is visible, audible, tangible, imaginable. As phenomenologists the effort is not to see deep into things in order to discover mysterious or hidden qualities, but to stay with the phenomenon long enough to see it as it is. 


\section{References}

Arendt, H. (1958). The human condition. University of Chicago Press.

Biesta, G. J. J. (2019. The rediscovery of teaching. Routledge.

Burch, R. (1989). Phenomenology and its practices. Phenomenology + Pedagogy, 7, 187-217.

Caputo, J. D. (1997). (Ed.). Deconstruction in a nutshell. Conversations with Jacques Derrida. Fordham University Press.

Dilthey, Wilhelm (1971). Schriften zur Pädagogik. Paderborn

Gadamer, H.-G. (1985). Truth and method. Crossroad.

Heidegger, M. (1962). Being and time. Blackwell Publishers.

Henriksson, C. \& Saevi, T. (2009). "An Event in Sound." Considerations on the ethicalesthetic traits of the hermeneutic phenomenological text. Phenomenology \& Practice, 3(1), 35-58.

Lewis, C. S. (1986). The abolition of man. Collins.

Marcel, G. (1951). The mystery of being. Vol. 1, Reflection and mystery [trans. G. S. Fraser] The Harvill Press.

Saevi, T. (2005). Seeing disability pedagogically. Doctoral dissertation. Norway: University of Bergen.

van Manen, M. (2014). Phenomenology of practice. Westcoast Press.

Wittgenstein, L. (1982-1992). Last writings on the philosophy of psychology. Vol. 1. Oxford: Basil Blackwell. G. H. von Wright \& Heikki Nyman (eds.).

Wood, D. (2002). Thinking after Heidegger. Blackwell Publishers Ltd. 